\title{
Integration of Web 2.0 Technologies into the Process of Students' Self-Directed English Learning
}

\author{
Julia V. Shishkovskaya \\ Associate Professor, National Research Tomsk Polytechnic University \\ Email: shishkovskaya_jv@mail.ru \\ Elvira Ya. Sokolova \\ Senior Teacher, National Research Tomsk Polytechnic University \\ Email: sokolovaeya@mail.ru
}

\section{Doi:10.5901/mjss.2015.v6n2p541}

\begin{abstract}
The recent study of the integration of Web 2.0 technologies effect on students' self-directed English learning and critical thinking skills updates the results and findings reported by the researches in this field. The purposes of this article is to analyze what constitutes the integration of Web 2.0 technologies into the process of students' self-directed English learning, to show what Web 2.0 tools can be used reasonably to intensify the students' motivation which results in the deliberate self-directed learning, and to elaborate upon various theories and researches concerning Web 2.0 technologies. The paper shows the real evidence of the development of foreign language communicative competences and skills including: reading, listening, speaking and critical thinking through such tools as podcasts, wiki and video online and offline, collaboration with one another in the form of peer review, self-reflection and making a blog. It was that concluded that it is necessary to develop and practice pedagogy and instructional strategy, along with the use of Web 2.0 technologies in order to achieve increased students' performance and efficiency of students' self-directed learning. It is to be emphasized that the specified problem needs further research to analyze the ways in fostering and benefiting student learning through Web 2.0 tools.
\end{abstract}

Keywords: self-directed learning; EFL teaching; Web 2.0; blog; educational webciety;

\section{Introduction}

At present, in the realm of EFL teaching we face an urgent necessity to develop a linguistic personality who tends to selfdirected learning foreign languages and cultures, to using huge amounts of information in a foreign language. To achieve this aim, we have to explore the current EFL teaching process in order to upgrade the material for self-directed learning, develop new teaching methods, techniques, and tutorials, and implement various types of self-directed exercises based on modern computer technologies.

The main teaching methods of methodological system implementation of students' self-directed English learning are as follows: training, problem-based learning (PBL), demonstration, communicative -interactive and creative-research. Upon the conducted research in the framework of our study we concluded that the integration of these methods has a positive impact on the development of the learning competence. The training method implementation is carried out in the various forms of control and self-control. The integration of blog technologies in the training method is the platform for students' self-actualization. The presentation of information in its various forms, such as video-, audio- text, graphs and etc. has become possible by means of information technologies. The use of slide presentations comes to the front. SlideShare service available at Web allows the participants to store, exchange, surf and use slide-presentations in students' learning activity. Problem based learning has an effect on knowledge acquisition and stimulates the thinking activity. The use of this method is aimed at shaping of students' critical thinking skills. Web-assignments in the format of Hotlist, Multimedia Scrapbook, Subject Sampler, Web Quest are used for the stage by stage study of any problem and besides contribute to the shaping of information competence as well as the development of learning competence.

Communicative-interactive method is based on the application of different telecommunication technologies. One of these technologies is blog-technology in combination with the service Web 2.0-Skype. The use of this method contributes to the development of speaking and especially writing.

The distinctive feature of problem based learning is its orientation on autonomous learning and students' 
awareness-raising. This method was introduced by J. Dewey (1997) and then developed by such Russian scientists as M.Yu. Bukharkina, M.V. Moiseyev, E.S. Polat. The emergence of information and communication technologies and their integration in the educational paradigm led to the quality new way of problem based learning which found its application in the form of telecommunication project which is often called as "web-projects". Upon the analysis of the above mentioned methods based on the study of their advantages and potential we came to the conclusion of the complex use of these technologies and methods in the framework of the developed methodological system. The leading methods, from our point of view, should be web-project which is aimed at the improvement of listening, speaking, reading and writing skills.

Federal State Educational Standard of Highest Vocational Education in Russia states the integration of innovative technologies into the educational process as one of the most efficient ways of its modernization. The use of e-Learning principles allows us to organize this process on a highly new level. The development of a virtual educational environment has made the former closed educational system open to the global community. Nowadays, it is considered that the use of Web technologies in education gives the passport to success to the future specialist.

Fundamentally, Web 2.0 is a platform which consolidates people into online communities, or Webcieties, allows two-way communication between the site and users, contributes to the authorship of the content and provides possibility to update the content by multiple authors. Now it is becoming increasingly clear that Internet should not be associated only with computer science due to such its characteristics as interactivity, creativity, availability, and sociality. The Web has been gradually changing its role in our lives: the role of a medium where the information was transmitted and consumed shifted to the role of a platform where we are able to create, share, remix, and repurpose the content. Moreover, it has become possible to communicate via Internet with the vocabulary consisting of words as well as images, video, and multimedia. In practice, this fact has resulted in the creation of educational Webcieties which have become the part of the academic setting. Surprisingly, I. Illich (1972) had formulated the main principles of creating any educational net or society long before Internet appeared. He stated that the presence of educational resources and any space for skills exchange as well the presence of the participants of such an exchange - all these make it possible to create an educational society. Nowadays Web 2.0 has become such a space for such an exchange, and Web 2.0 tools have become a new form of the knowledge store and a new way of its implementation, governance, and evaluation inside the educational communities.

The main principles of Web 2.0-based learning provided the basis for the introduction of the nomenclature "Education 2.0". Education 2.0 is highly digitized as it is aimed at an intensive use of Web 2.0 technologies in an educational process. Education 2.0, opposite to Education 1.0, is an open learning management system when students are not passive knowledge consumers anymore but are engaged into a collaborative work, and actively build their knowledge without an excessive teacher control. Thus, the role of a traditional authoritarian teacher, "knowledge-giver", has changed to the more open role of a guide, a helper, "knowledge-manager". The educator's objective is to teach students how to gather and compile the educational information, and implement it properly in their studies. It is important to relax a teacher control which will result in students' development of a sense of ownership toward their work, and will lead to the intensity of their motivation and engagement. The learning activities have become more open and flexible, and focus on creating room for student creativity and social networking outside traditional boundaries of discipline, institution, and country. As a result of such learning, students have become more initiative and participative, less affiliative and passive absorptive. In our view, S. Hargadon(2008) gives one of the best descriptions of the educational process based on Education 2.0 conception. He advocates that there has been the shift "from consuming to producing, from authority to transparency, from the expert to the facilitator, from the lecture to the hallway, from "access to information" to "access to people", from "learning about" to "learning to be", from passive to passionate learning, from presentation to participation, from publication to conversation, from formal schooling to lifelong learning, from supply-push to demand-pull". At the same time, integrating Web 2.0 technologies into ESL teaching, we should not lose sight of the importance of one of the main teaching principles - the principle of pedagogical usefulness of using Information and Communication Technologies in education. The utility of implementing computer technologies in educational process can be measured by their teaching efficiency compared to traditional teaching methods. In practice, every educator who is eager to use Web technologies has to know the principles of their implementation, realize the reasons of it, and be able to customize the existing teaching techniques of using Web technologies to the current curriculum.

Recently, more and more teachers have used Web technologies to manage the students' self-directed learning process. P. Sisoev (2009) claims that Web 2.0 tools easily found its way into teaching practice due to their efficiency (an easy way of gathering information based on tags, or key words), giving the opportunity to create a private space in the net, lack of the necessity of HTML-language and programming learning, as well as giving the opportunity to participate in these tools development. Having proved successful, Web 2.0 technologies have resulted in the global decentralization of 
the Internet. The contents of the sites have become dependent on the users themselves. Moreover, the users altogether can now create a new Internet-page, a blog, for example, and fill it with the necessary information online. A blog, a main mean of communication online, is a virtual private diary. Recently, there has been a great integration of blog-technologies into the educational process as they help teachers deal with such problems as the creation of consistent educational environment for teachers and their students, keeping in touch with all the members of the educational Webciety, using eLearning (putting courses online, online testing, etc.). A.P. Campbell (2005) outlines the features which make blogging attractive to EFL educators: a blog has "a simple, user-friendly, intuitive interface", and a WYSIWYG text editor; it helps the learners moderate comments, and customize their pages to their individual preferences; it has a built-in aggregator, and allows students to easily post and share photo, sound, and video files; it has the function of setting up the privacy and control.

It is necessary to observe that using Web 2.0 tools to manage the students' self-directed learning foreign languages process has its own peculiarities. Within the academic setting, we consider self-directed learning as an educational activity focused on the integrated development of the informational, learning and foreign language communicative competences. This process is based on the competency building approach, and is put into practice by students' self-directed learning of a new topic (by means of using authentic Internet-sources - blogs, podcasts, sites, video, etc.); students' self-directed use of Web 2.0 tools to gather, compile and publish a new information in a foreign language; students' self-directed evaluation of the their educational activities outcome and its correcting. The main tools of the self-directed learning are Web 2.0 tools; Internet access should be provided during all educational process. The system of evaluation includes self-check, teacher's check, and the check of all the members of the educational Webciety and the Internet. The evaluation criteria of the quality of the self-directed learning has to include the motivation factor, as well as the knowledge and skills peculiar to the informational, learning and foreign language communicative competences altogether. We determined the following criteria:

a) Motivation to the use of Web 2.0 tools.

b) Knowledge about the sources of the foreign information.

c) Knowledge about principles and techniques of dealing with foreign information based on Web 2.0 technologies.

d) Skills of gathering, compiling, sharing the foreign information using Web 2.0 technologies.

e) Skills of using Web 2.0 technologies according to the stated objectives.

f) Skills of defining the objective and ways of its pursuing using Web 2.0 technologies.

g) Skills of forecasting, analyzing, and evaluating the work results.

h) Appropriate use of English writing, speaking, listening, and reading skills.

\section{Scientific Research}

The aim of the scientific research conducted on the basis of National Research Tomsk Polytechnic University (NR TPU) was to verify the pedagogical efficiency of the integration of Web 2.0 technologies into the students' self-directed English learning process inside the academic setting. The e-learning course based on the integration of Web 2.0 technologies into the students' self-directed English learning process was designed according to curriculum objectives and pedagogical theories to help students master their listening, speaking, reading skills and improve English narrative writing in English for General Purposes (EGP). The experience from this study showed when reasonably and appropriately used the Web 2.0 technologies have a high potential to increase students' motivation, effectively support teaching and learning activities and enhance teaching and learning opportunities by means of different tools such as wiki, blogs, forums, glossaries, workshop, databases, quizzes, three dimensional (3-D) immersive virtual worlds, social bookmarking tools such as Delicious (http://delicious.com), audio podcast and YouTube (http://www.youtube.com) and other resources.

To achieve these goals, we divided the second-year-students of Power Engineering Institute of NR TPU into two groups: experimental and control. The educational process of the students in the experimental group was oriented into the active use of Web 2.0 technologies. Meanwhile, the students in the control group were planned to be taught in a traditional way. The research was carried out into two stages. At the first stage we examined the current students' selfdirected English learning process; conducted the surveys aimed at defining the students' motivation to the use of Web 2.0 tools and to the process of self-directed English learning. The results of our investigation showed that the students of both groups had a low inner motivation to self-directed English learning. Interestingly, the survey revealed a high level of students' motivation to using Internet in their studies. We also tested the students' English language level, and stated that most of them had the Pre-Intermediate level. The students were also offered to make a presentation in Microsoft Power Point on a given topic, and the main condition was to use as many Web 2.0 tools for its performance as they were able 
to. The project outcome showed the lack of students' knowledge and skills of successful working with Web 2.0 tools. The results received at the first stage of the research proved the necessity of integration of Web 2.0 technologies into the educational process of EFL teaching.

The teaching system of using Web 2.0 technologies for managing the students' self-directed English learning process carried out during the second stage of our research was based on two main pedagogical approaches: constructionist where learning occurs by creating and developing a product in accordance with the specified assignments; and co-constructive where groups of learners complete a series of goal-related tasks to produce the final project. The main class activity in the framework of the final project development was to create a student's blog online. However, this activity was supposed to be preceded by the classes devoted to learning basic Web 2.0 tools and the main principles of their work. They are: work with the teacher's blog, work with Web 2.0 tools.

The teacher's blog has several functional capabilities: instructions concerning Web 2.0 tools, the use of publication of the educational materials (curriculum, lectures, etc.), publication of the home assignment, conducting various surveys, comments to any message, etc.

The work with Web 2.0 tools implies language mastery. The development of the reading skills means publication of the links onto different texts online, or using Google Disk attached to the teacher's blog. The students are also offered to use social bookmark managers such as Delicious where they are able to gather pertinent information by tags. Wordle, the tool for generating "word clouds" from any text, is very helpful when a teacher wants to engage students, and promote a further conversation. The listening skills are developed by using podcasts and video online and offline. The writing skills are improved by publishing comments to messages, collaboration with one another in the form of peer review, selfreflection and making a blog. The platform Dvolver Movie Maker gives students the opportunity to make a digital movie online where the talks of the characters are written by the learners themselves. Another way to practice in writing is to communicate with a virtual chatter robot. The speaking skills can be developed by students' making their own podcasts and publishing them online.

The teaching assignments, stated above, served as a basis for the final Web-project - making a student's blog. They were aimed at the integrated development of the informational, learning and foreign language communicative competences of students up to the level sufficient for their successful work on the web-project. At the first stage of creating a student's blog, the learners were offered to work out the project details, formulate the objective and main issues. Then, they were required to study the issue using various Web 2.0 tools for compiling, analyzing, and synthesizing the information. The third stage was making and evaluating the blog. The task of the students was to perform the problem under study through various data-collection Internet techniques, using different Web 2.0 tools. To make the process more clear, we established the guidelines both for teachers and students on how to work on a Webproject. Thus, for maximizing the benefits of the work a teacher should obey the following rules:

a) Conduct students' questionnaire survey and interview to find out student's interests and needs.

b) Within the curriculum, determine the issues for the students' self-guided learning.

c) Determine and formulate the topic of the Web-project work. The topic is also possible to be determined by students.

d) Determine the objective of the Web-project work. The objective is also possible to be determined by students.

e) Determine the methods and techniques necessary for the efficient outcome of the Web-project work.

f) Work out the timetable for students.

g) Brief on students about the curriculum, evaluation criteria, evaluation stages, etc.

h) Determine and introduce to students the tutorial and appointment calendar.

i) Evaluate the final product according to the evaluation criteria.

We also suggest the following guidelines for students:

a) Determine and formulate the topic of the Web-project work. The topic is also possible to be determined by a teacher.

b) Determine the objective of the Web-project work. The objective is also possible to be determined by a teacher.

c) Work out a draft of the future Web-project work.

d) Determine the linguistic means, Web 2.0 tools necessary for the work.

e) With the help of the chosen tools, gather the pertinent information. It has to be presented in various ways hypertext, podcasting, video, etc.

f) Analyze the information in terms of its relevance and purposefulness.

g) Compile the information according to the draft.

h) Create your blog.

i) Evaluate the blog according to the given criteria. 
j) Make some corrections if necessary. If you have any problems at any step, consult the teacher.

\section{Results}

The results of the scientific research based on the realization of the established teaching system of Web 2.0 tools integration into ESL teaching process showed the increase of the students' motivation to self-directed English learning in the experimental group (33\% more than in the control group). There can be defined the growth of the number of students with a high level of their Web-project work quality in the experimental group (30\% more). As for the students' language level, $4 \%$ of the students of the experimental group reached the Upper-Intermediate level.

\section{Conclusion}

To summarize it briefly, we may state that the efficiency of students' self-directed English learning is grounded in the integrated development of their informational, learning and foreign language communicative competences, and in the improved learning materials based on using Web 2.0 technologies in educational process. The incorporation of Education 2.0 principles and techniques into academic setting leads to increase of educational potential which is reflected in a general positive impact on students' achievement and increased motivation, autonomy, engagement, positive attitude toward their studies. Moreover, it allows to enhance critical thinking and decision-making abilities. It is to be noted that there is great potential for using Web 2.0 technologies for student learning as they provide information to help educators with actual classroom ideas to achieve specific learning goals and contribute to personal learning network maintenance. However, in order to achieve increased students' performance and efficiency of students' self-directed learning it is necessary to develop and practice pedagogy and instructional strategy, along with the use of Web 2.0 technologies. This problem needs further research to analyze the ways in fostering and benefiting student learning through Web 2.0 tools.

\section{References}

Campbell, A.P., (2005) Weblog Applications for EFL/ESL Classroom Blogging: A Comparative Review // TESL-EJ. 3(9). [Online] Available: http://tesl-ej.org/ej35/m1.html (June 16, 2014)

Dewey, J. (1997) Psychology and Pedagogy of Mind. Moscow Sovershenstvo Publ, 208 p.

Hargadon, S., (2008), Web 2.0 Is the Future of Education. [Online] Available: http://www.stevehargadon.com/2008/03/web-20-is-futureof-education.html (October 4, 2014)

Illich, I.(1972) Deschooling Society. New York, 107 p.

Sisoev, P.V. (2009). Web 2.0 technologies in the creation of virtual educational environment fora foreign language learning. Foreign languages at school. Moscow, 3, pp. 26-31. 